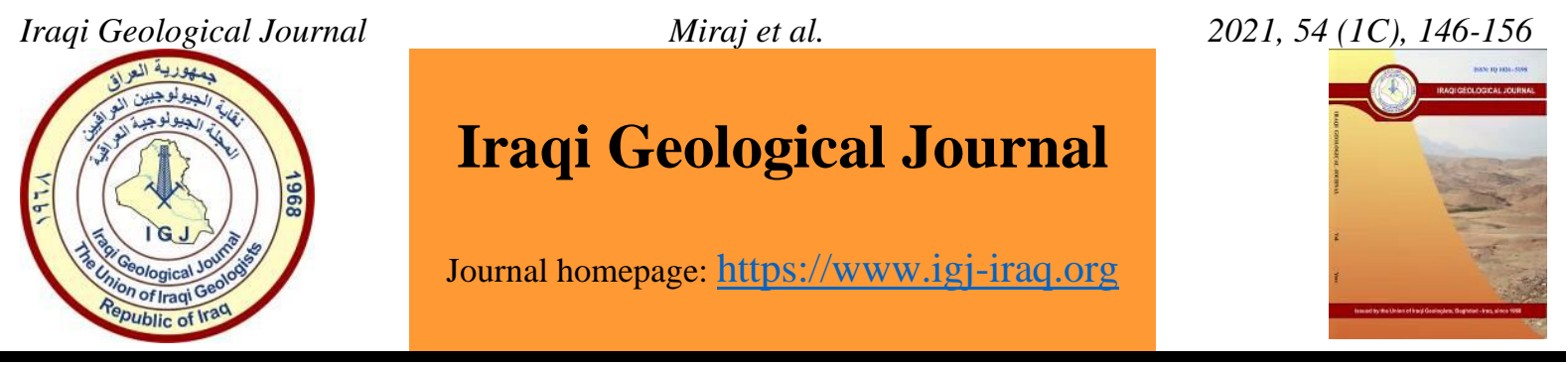

\title{
Subsurface Structural Interpretation of Missa Keswal Area, Eastern Potwar, Pakistan
}

\author{
Muhammad Armaghan Faisal Miraj ${ }^{1, ~ *}$, Muhammad Zubair Idrees ${ }^{1}$ and Shan Shahzad $^{1}$ \\ ${ }^{1}$ Institute of Geology, University of the Punjab, Quaid-e-Azam Campus-54590, Lahore, Pakistan \\ *Correspondence: armghan.geo@pu.edu.pk
}

Received: 12 November 2020; Accepted: 20 January 2021; Published: 31 March 2021

\begin{abstract}
Potwar Basin is although a hydrocarbon prolific basin but shows mixed scenarios regarding the success ratio of the wells. Several wells are producing good but a significant number of wells ended up with a great loss. Missa Keswal area is also a part of the Potwar Basin which was discovered in 1991. The main objective of this research is to find the subsurface structure of the Missa Keswal area with the help of seven seismic lines, 3-D modeling and the correlation of five wells. Kingdom suite 8.8 is the main software used to delineate the subsurface structure along with some other software. Results indicate that the tectonic framework of the study area is mainly controlled by the Jhelum strike slip fault and decollement layer i.e., Pre-Cambrian salt. Structural analysis shows that the study area bears NE-SW trending salt cored pop-up anticlinal structure bounded by major thrust fault and back thrust. Patala Formation acts as a source, Lockhart Limestone, Sakesar Limestone and Chorgali Formation acts as a reservoir while fault surface (often acts a good conduit) and Neogene clays providing a potential sealing mechanism for entrapment.
\end{abstract}

Keywords: Potwar Basin; Missa Keswal; 3-D modeling; Strike slip fault; Pop-up; back thrust

\section{Introduction}

Pangea, a recent supercontinent, was formed during the Late Paleozoic that remained intact for about 100 million years. By the end of the Late Triassic, it splits into Laurasia and Gondwanaland with Tethys seaway. Indo-Pak Plate was the part of Gondwanaland that drifted toward north about 130 million years ago. The drifting speed remained variable throughout the course of flight and finally collided with Eurasian Plate (Kazmi and Jan, 1997).

Pakistan is a geological museum in which upheaval and erosion of the Himalayas are ongoing (Ahsan et al. 2013; Powell, 1979). Himalayan orogenic belt is a significant outcome of the collision of Indo-Pak and Eurasian landmasses about 55-50 million years ago (Bouilhol et al. 2013; Searle et al. 1987; Yin and Harrison, 2000) and a suture zone developed named as Indus-Tsangpo Suture zone (Valdiya, 2002). The Pakistani part of Himalayas categorized into a number of tectonostratigraphic zones (Farah et al., 1984; Yeats and Lawrence, 1984) as Main Karakoram Thrust (MKT), Main Mantle Thrust (MMT), Main Boundary Thrust (MBT) and Salt Range Thrust (SRT) (DiPietro and Pogue, 2004; Gill and Rajaran, 2009) (Fig. 1). Potwar Basin incorporates tectonically complex deformation style. It is a Himalayan foreland zone formed due to the thrusting of above discussed landmasses (Drewes, 1995). Due to the different levels of decollement surfaces, surficial structures were not giving the true

DOI: $10.46717 /$ igj.54.1C.11Ms-2021-03-31 
picture of subsurface structures (Moghal et al. 2007). So, there is a need to integrate the seismic data along with geological data to delineate the true subsurface structural configuration. Hydrocarbon is an important and significant economic element of any country. Therefore, the maximum input is required to map the surficial as well as the subsurface structure to find a productive source and reservoir rock. A lot of publications have been made on sedimentary basins of Pakistan and focuses on a point that mega structures are still needed to exploit and to fulfil the need. Being the oldest explored basin (Potwar Basin), it must be exploited more to discover the more hydrocarbons. Most of the wells did not make a hit due to the prevailed drilling complications and traditional technology. By using advanced technology, Plug and abandoned wells are retested and resulted in success (Jadoon et al. 2015, Moghal et al. 2007, Qaudri and Qaudri 1998). Potwar Basin is well producing from Cambrian, Permian, Paleocene, Eocene and Miocene sequences.

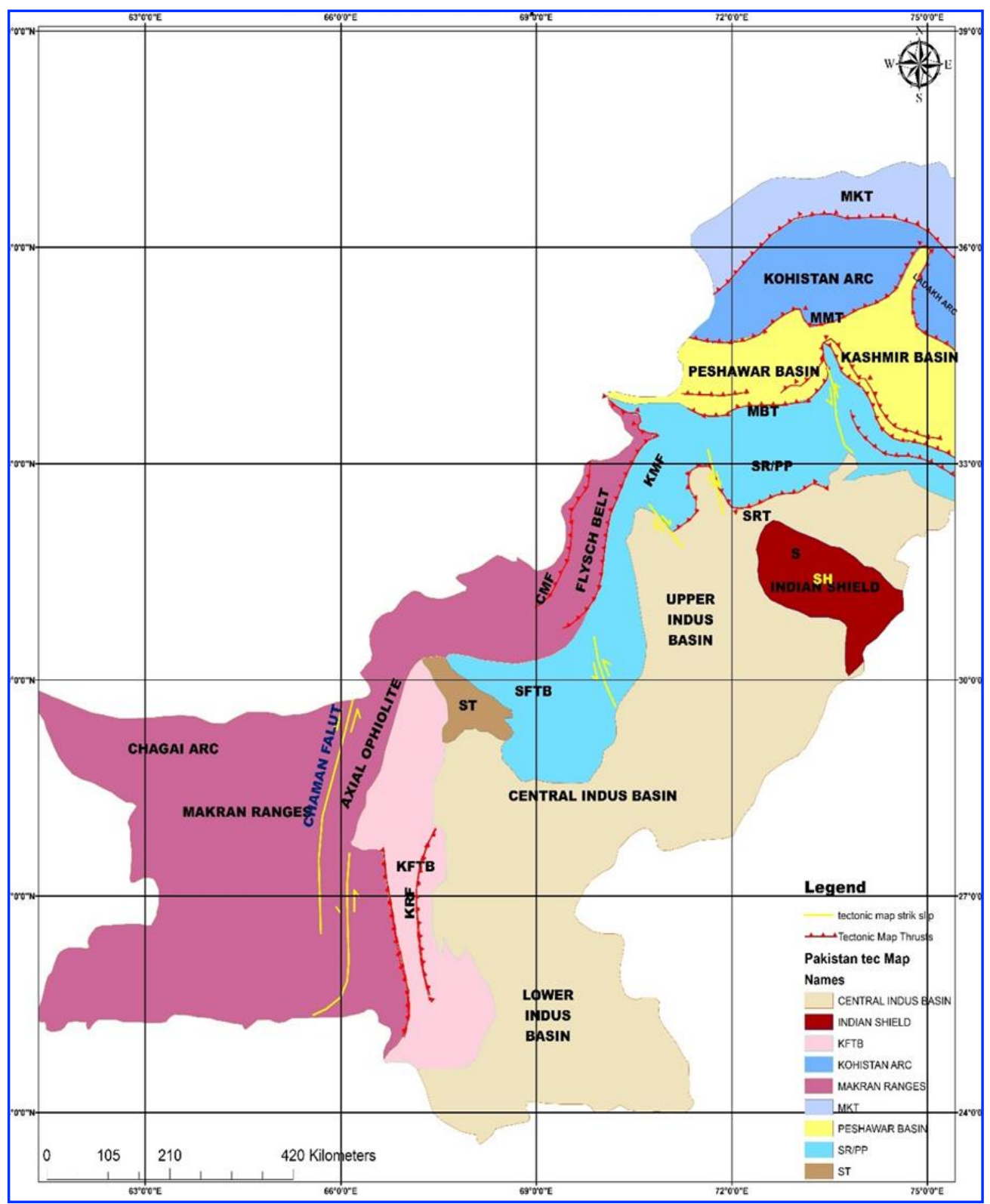

Fig. 1. Generalized tectonic map of Pakistan (Modified after Davis and Lillie, 1994)

Geographically, the Missa Keswal area is located ten kilometers away from Gujar Khan or about $60 \mathrm{~km}$ in south-east of Islamabad. It lies between the latitudes $33^{\circ} 11^{\prime} 06^{\prime \prime}$ and $33^{\circ} 12^{\prime} 18.24^{\prime \prime} \mathrm{N}$ and longitudes from $73^{\circ} 16^{\prime} 42^{\prime \prime}$ to $73^{\circ} 18^{\prime} 00^{\prime \prime}$ E (Fig. 2). Geologically, it lies in the eastern part of the 
Potwar Basin (Upper Indus Basin) of Pakistan. Eastern, western, northern and southern extremity of the Potwar Basin is marked by Jhelum strike slip fault, Kalabagh strike slip fault, MBT and SRT respectively (Fig. 2). Surficial expressions of the study area show the thrust bounded anticlinal structure which oriented in NE-SW direction.

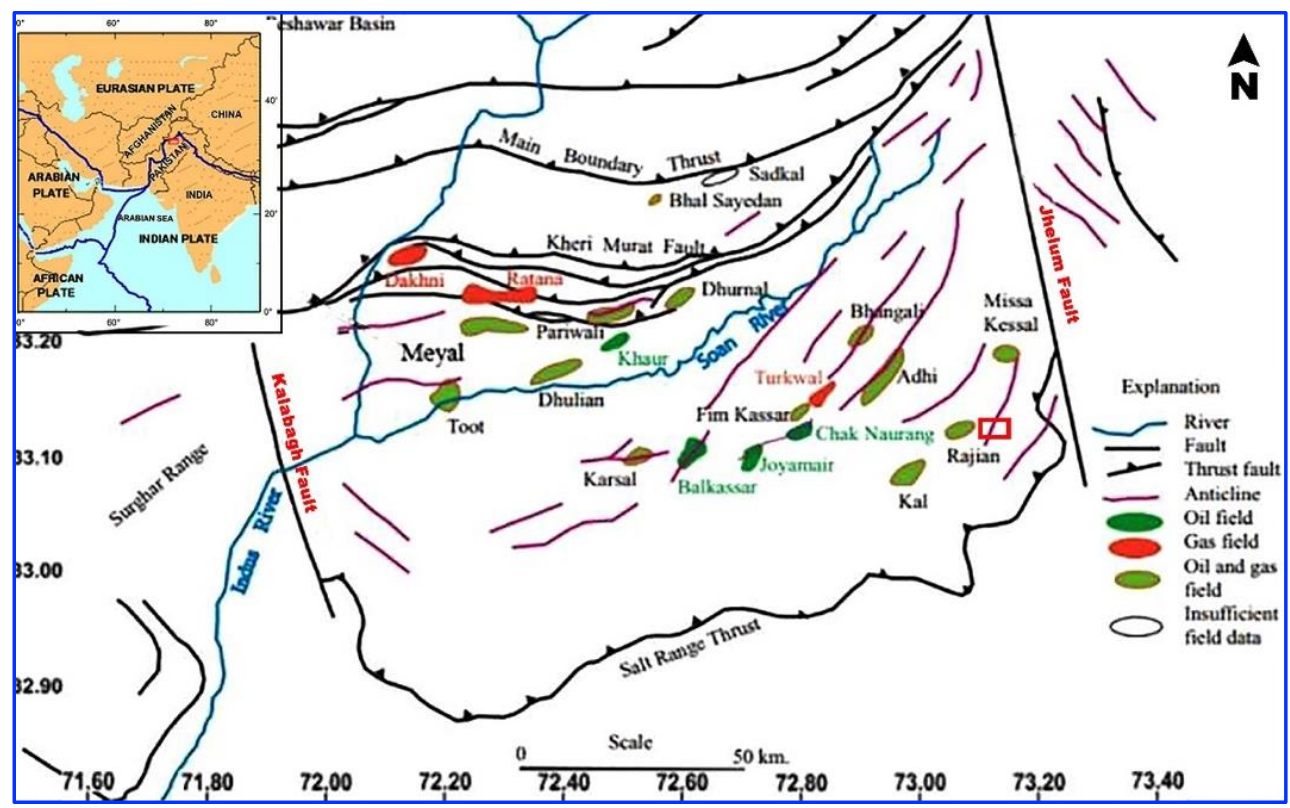

Fig. 2. Locational map of the study area with different tectonic boundaries (Modified after Kazmi and Rana, 1982; Khan et al. 1986; Wandrey et al. 2004)

Thick evaporitic facies of the Pre-Cambrian are overlain by comparatively thin platform deposits of Cambrian-Eocene followed by Molasses of Miocene to Pliocene deposits (Fig. 3). The whole sequence of the Potwar Basin is highly deformed due to the different decollement layers and by extensive orogenic events of the Himalayas during Pliocene to Middle Pleistocene (Moghal et al. 2007).

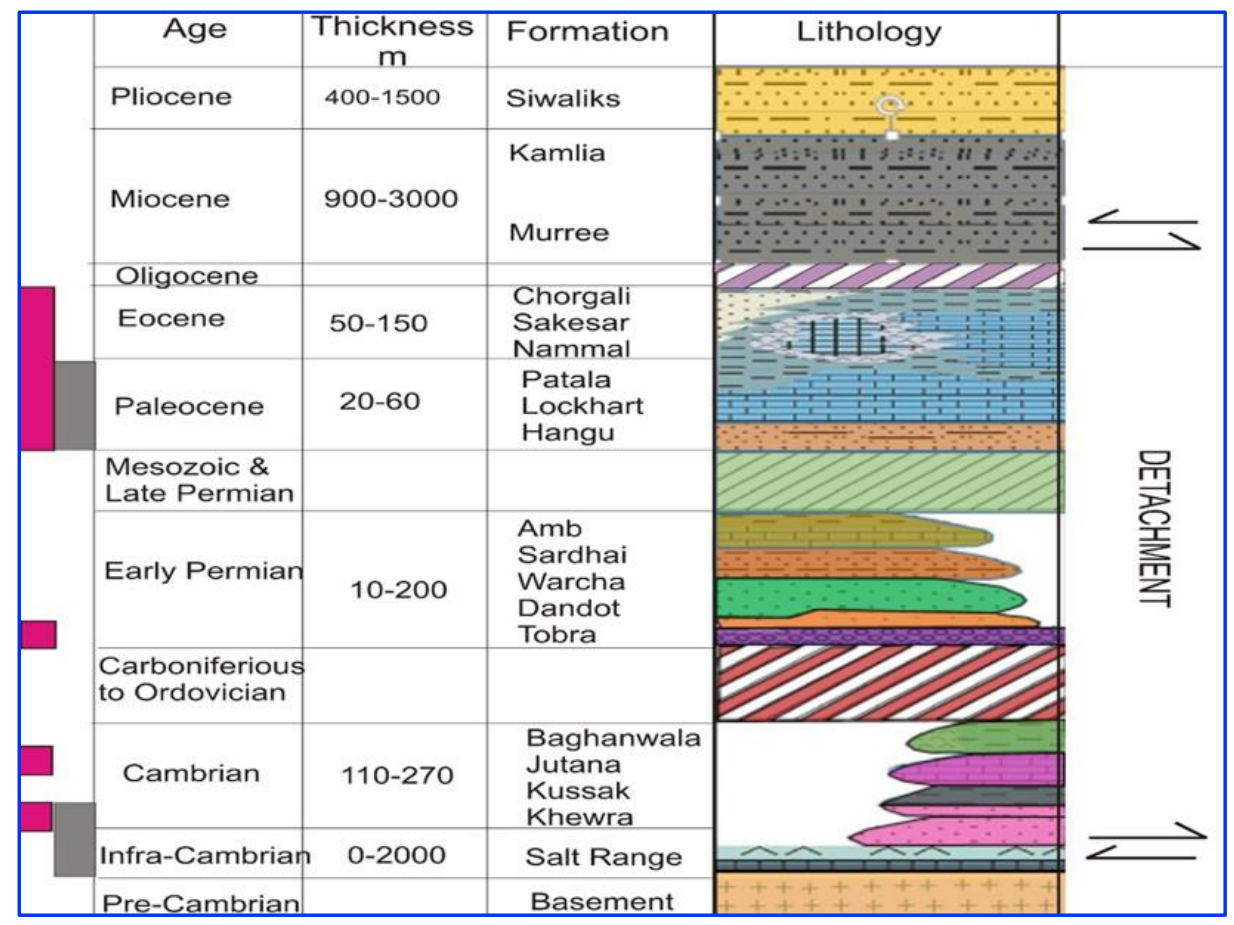

Fig .3. Schematic stratigraphic column of the eastern Potwar (Aamir and Siddiqui, 2006) 
Previous studies were not focused on 3-D modeling of different zones of interest to interpret the true subsurface picture. As surficial geological data misguided while interpreting the subsurface structure. Therefore, there is need to integrate seismic data along with well data to overcome this issue. The present study focuses on to delineate the subsurface structure with 3-D modeling. Moreover, the correlation of wells of Missa Keswal area with different surrounding wells is also under study.

\section{Materials and Methods}

Data was provided by the Directorate General of Petroleum Concessions (DGPC). Seven seismic lines (GNA-09, GNA-10, GNA-11, GNA-14, GNA-16, GNA-19 and GNA-20) of the Missa Keswal area were opted to investigate the subsurface structure style via seismic interpretation of reflectors as opted by Ali and Kadhim, 2020. In addition to this, well data in LAS file was used to display on base map and then correlated both the dip and strike oriented wells of study area with surrounding wells [Missa Keswal-01 (MK-01), Missa Keswal-02 (MK-02), Missa Keswal-03 (MK-03), Adhi-14 (A-14) and Shahab-01 (Sh-01)]. The distance between Missa Keswal-01 and Missa Keswal-02 is $2.61 \mathrm{Km}$, Missa Keswal-02 and Missa Keswal-03 is 3.29 Km while the Missa Keswal-01 and Missa Keswal-03 are $5.91 \mathrm{Km}$ far apart. Missa Keswal-02 and Shahab-01 are $24.8 \mathrm{Km}$, Adhi-14 and Missa Keswal-02 is $31.9 \mathrm{Km}$ while Shahab-01 and Adhi-14 are $55 \mathrm{Km}$ far apart. Wireline logs were helpful for making graphical logs. Kingdom suite 8.8 software was used to delineate the subsurface structural analysis along with 3-D modeling. Some other softwares were also helpful and used to fulfil the core objectives, i.e., ArcGIS 10.7 was employed for georeferencing and map making (LogPlot used for logs and correlation of different wells, Adobe Photoshop and CorelDRAW X8 for graphical modifications. Base map of the study area is shown in Fig. 4.

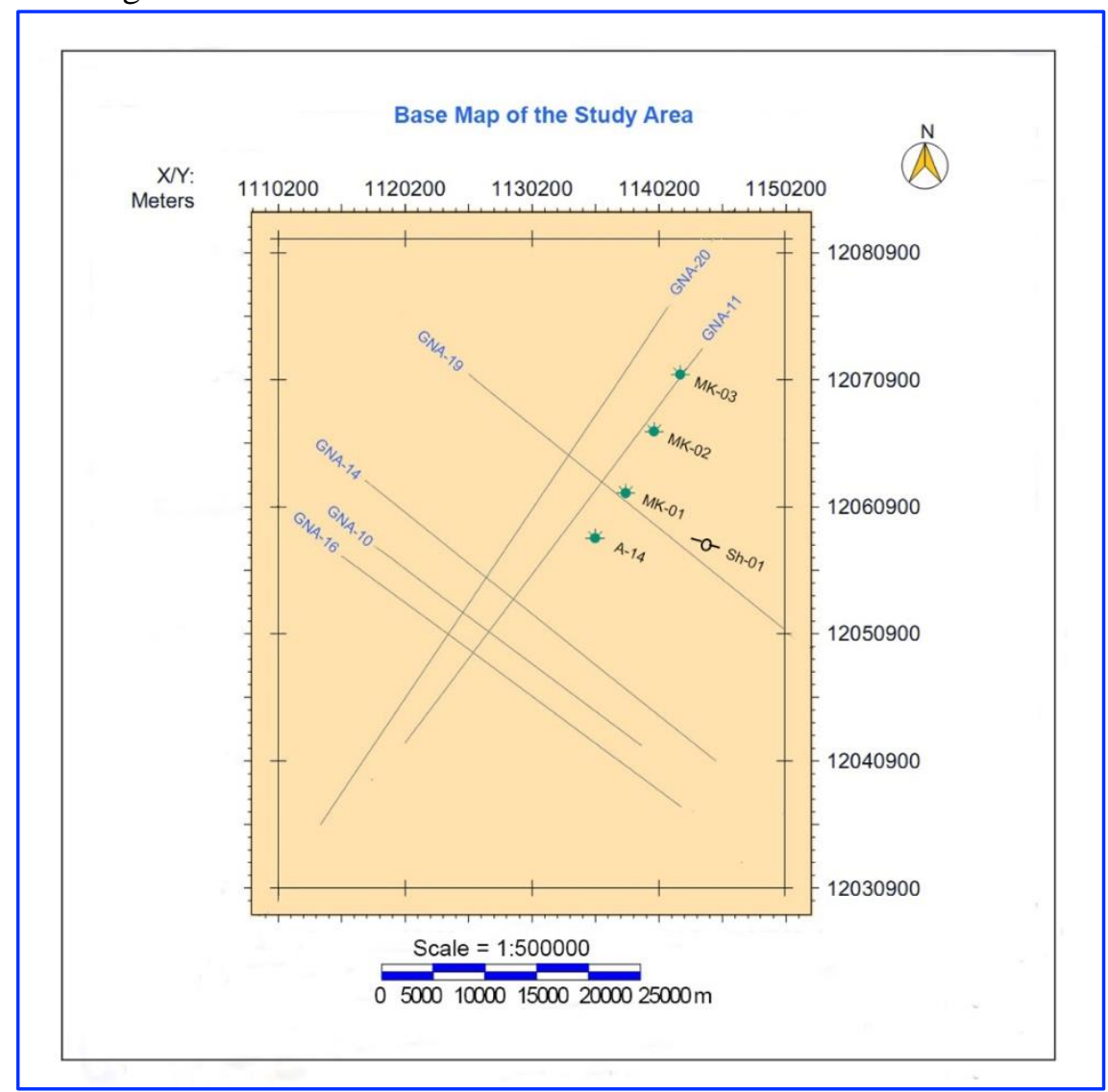

Fig. 4. Base map with strike and dip oriented seismic lines along with wells Missa Keswal-01 (MK-01), Missa Keswal-02 (MK-02), Missa Keswal-03 (MK-03), Adhi-14 (A-14) and Shahab-01 (Sh-01) 


\section{Results}

Results were categorized into four parts as seismic data interpretation, 3-D modeling, well correlation, and finally the comparative structural analysis of the Missa Keswal area with the whole Potwar Basin. The detailed results are as follows:

\subsection{Seismic Data Interpretation}

GNA-10, GNA-14, GNA-16 and GNA-19 showing NW-SE oriented dip lines (Fig. 4) which showing three prominent reflectors of different packages, i.e., Chorgali Formation and Sakesar Limestone of Eocene while Lockhart Limestone of Paleocene (Fig. 5 and Fig. 6). A major Thrust 1 and back thrust terminated the continuity of the reflectors. In addition to this, an additional small thrust that lies behind the back thrust that may be resulted due to the back thrust. All these thrusts collectively form pop up structure.

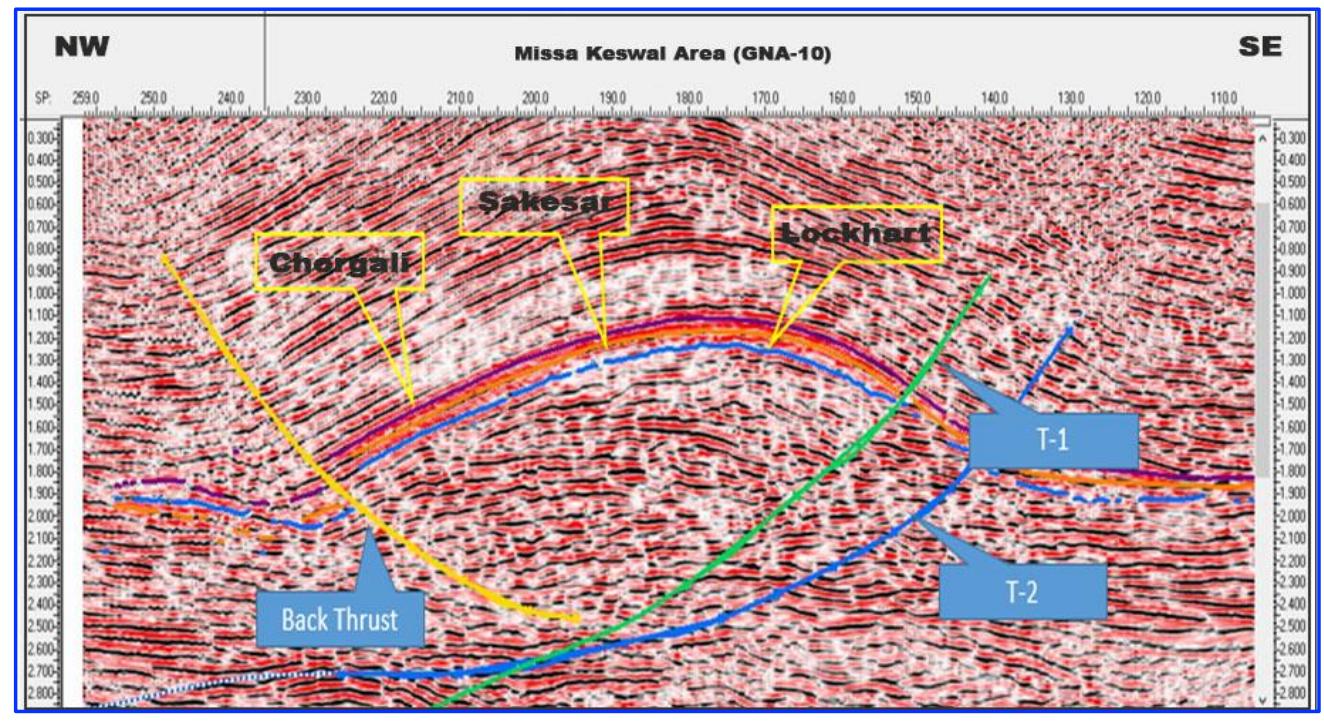

Fig. 5. Interpreted structure of GNA-10 seismic line (Scale=1:500000). Orientation can be seen in Fig. 3

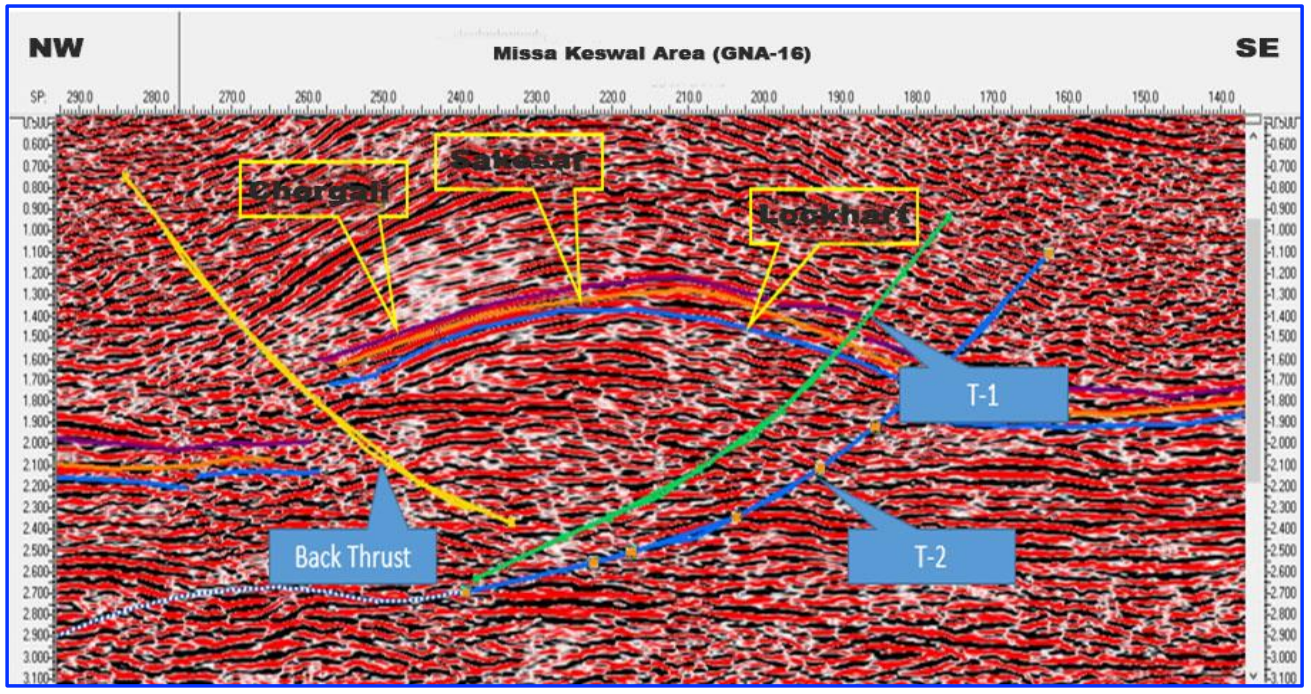

Fig. 6. Interpreted structure of GNA-16 seismic line (Scale=1:500000). Orientation can be seen in Fig. 3

GNA-11 and GNA-20 were NE-SW oriented strike lines showing three prominent reflectors indicated the formations (Chorgali Formation, Sakesar Limestone, Lockhart Limestone) just like dip 
lines. But these reflectors were the indicator of the undisturbed packages showing continuity or lateral extension of the formations. As study area lies close to the collisional zone, that's why, it is severely deformed by developing anticlinal structure in the study area. Such structural development may be due to the combined effect of salt diapirism and the strike slip movement of the thrust faults near left lateral strike slip Jhelum Fault.

\subsection{3-D Modeling}

3-D model of Missa Keswal anticline at the Eocene horizon of Chorgali Formation is shown in Fig. 7. Folding and thrusting can easily be visualized from the model. Asymmetric anticlinal folding is observed in which north-western limb is steeper as compared to south-eastern limb, that one was quite gentle. Overall, the thrust along with its imbrication dipping towards north-western side while opposite dip direction noticed in case of back thrust. Due to the plunging structure, it may provide a closure for the hydrocarbons. Similar structural trend was observed in case of Sakesar Limestone of Eocene (Fig. $8)$.

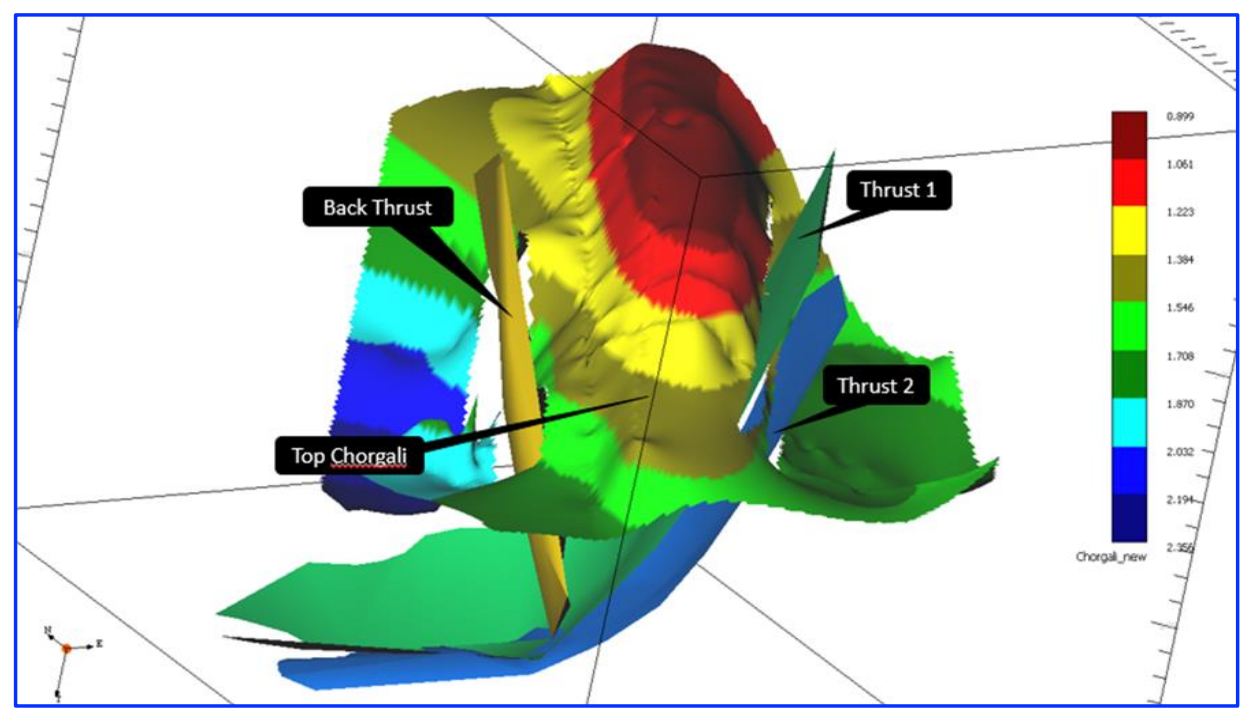

Fig. 7. 3-D structural model of Missa Keswal anticline at the level of Eocene horizon (Chorgali Formation)

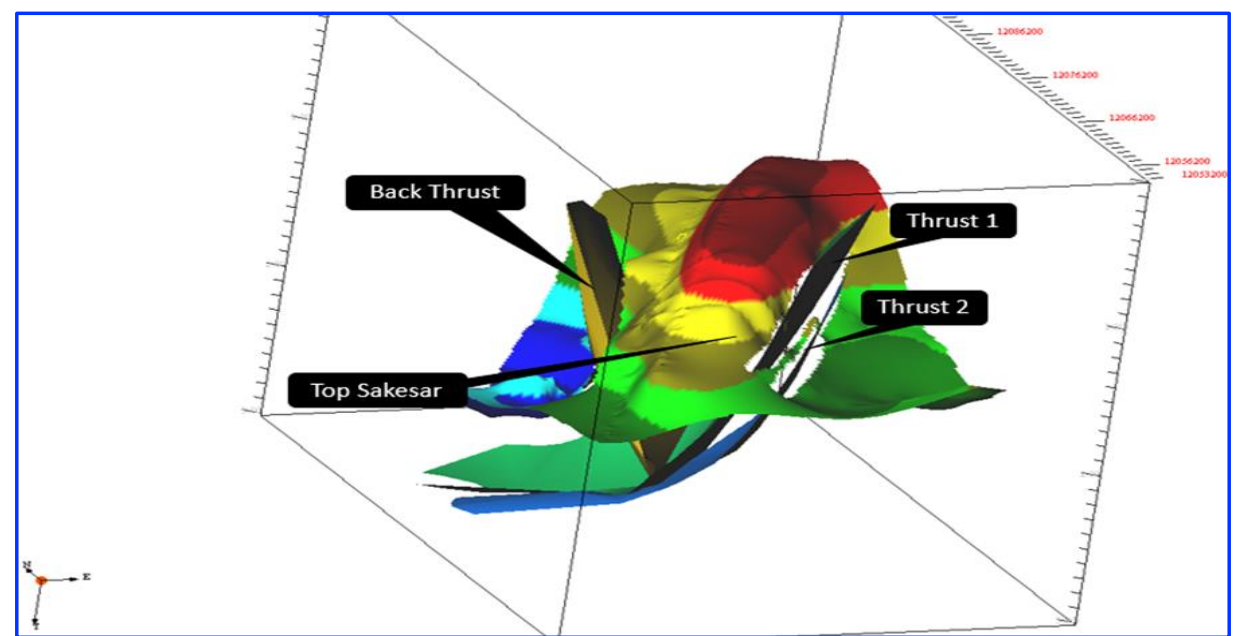

Fig. 8. 3-D structural model of Missa Keswal anticline at the level of Eocene horizon (Sakesar Limestone)

In general, the anticline structural trend was almost the same from Eocene (Chorgali Formation and Sakesar Limestone) to Paleocene (Lockhart Limestone). However, below that Paleocene package, 
an effect of salt diapirism was noticed. Further below that package, smooth to gently dipping basement was found (Fig. 9).

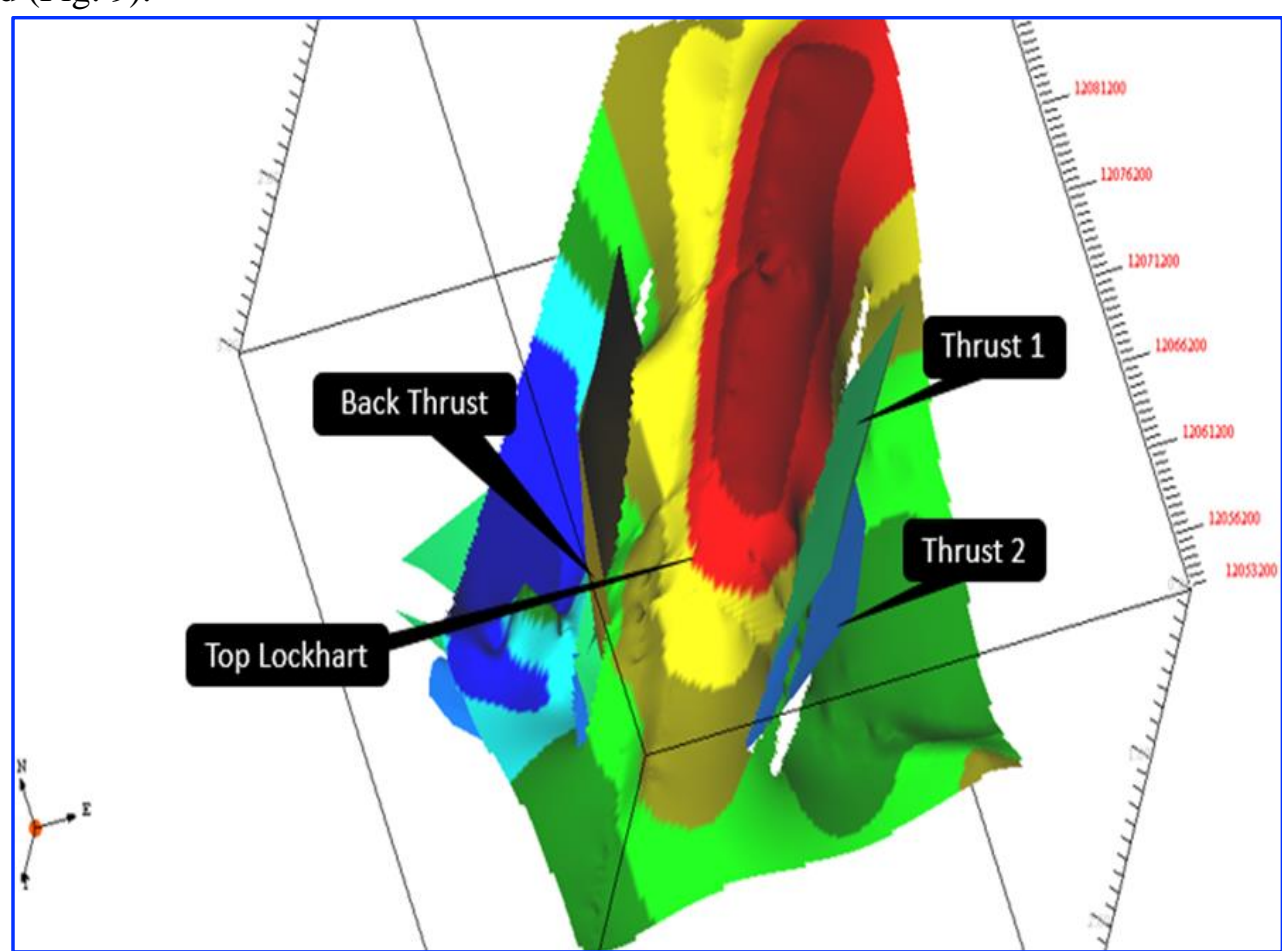

Fig. 9. 3-D structural model of Missa Keswal anticline at level of Paleocene horizon (Lockhart Limestone)

\subsection{Well Correlation}

For well correlation, five wells were selected to study the subsurface geology and stratigraphy of the Missa Keswal area. Out of which three were strike oriented while two wells of Eastern part of Potwar were dip oriented (Fig. 10, Fig 11). Missa Keswal-01, Missa Keswal-02 and Missa Keswal-03 were selected for correlation. The distance between Missa Keswal-01 and Missa Keswal-02 is 2.61 Km, Missa Keswal-02 and Missa Keswal-03 is 3.29 Km while the Missa Keswal-01 and Missa Keswal-03 are 5.91 $\mathrm{Km}$ far apart. Variation in the thickness of different stratigraphic packages can be observed in Fig. 10 from SSW to NNE. A complete sequence was present from Salt Range Formation of Pre-Cambrian to Chinji Formation of Miocene. At the base, variable thickness of Pre-Cambrian salt was present in both Missa Keswal-01 (23m) and Missa Keswal-02 (2m) wells and acts as decollement. Cambrian to Eocene sequence was present in all the wells but with varying thickness. Salt lifted up this overlying sequence from SSW to NNE (Fig. 10). Plunging structure formed from Missa Keswal-01 to Missa Keswal-03 due to these structural variations. Shahab-01 (east) to Adhi-14 (west) were dip oriented wells and can be seen in Fig. 11. Between these two wells, Missa Keswal-02 was present. Missa Keswal-02 and Shahab01 are $24.8 \mathrm{Km}$, Adhi-14 and Missa Keswal-02 is $31.9 \mathrm{Km}$ while Shahab-01 and Adhi-14 are $55 \mathrm{Km}$ far apart. Pre-Cambrian to Miocene sequence present in Shahab-01 and Adhi-14 while Cambrian to Miocene sequence encountered in Missa Keswal-02. During Early and Middle Miocene when Murree Formation was deposited, because the older and younger formations than Murree Formation, are preserved their thickness whereas Murree Fm did not be due to the uplift. It can be confirmed by thin preservation of Murree Formation in Missa Keswal-02. 


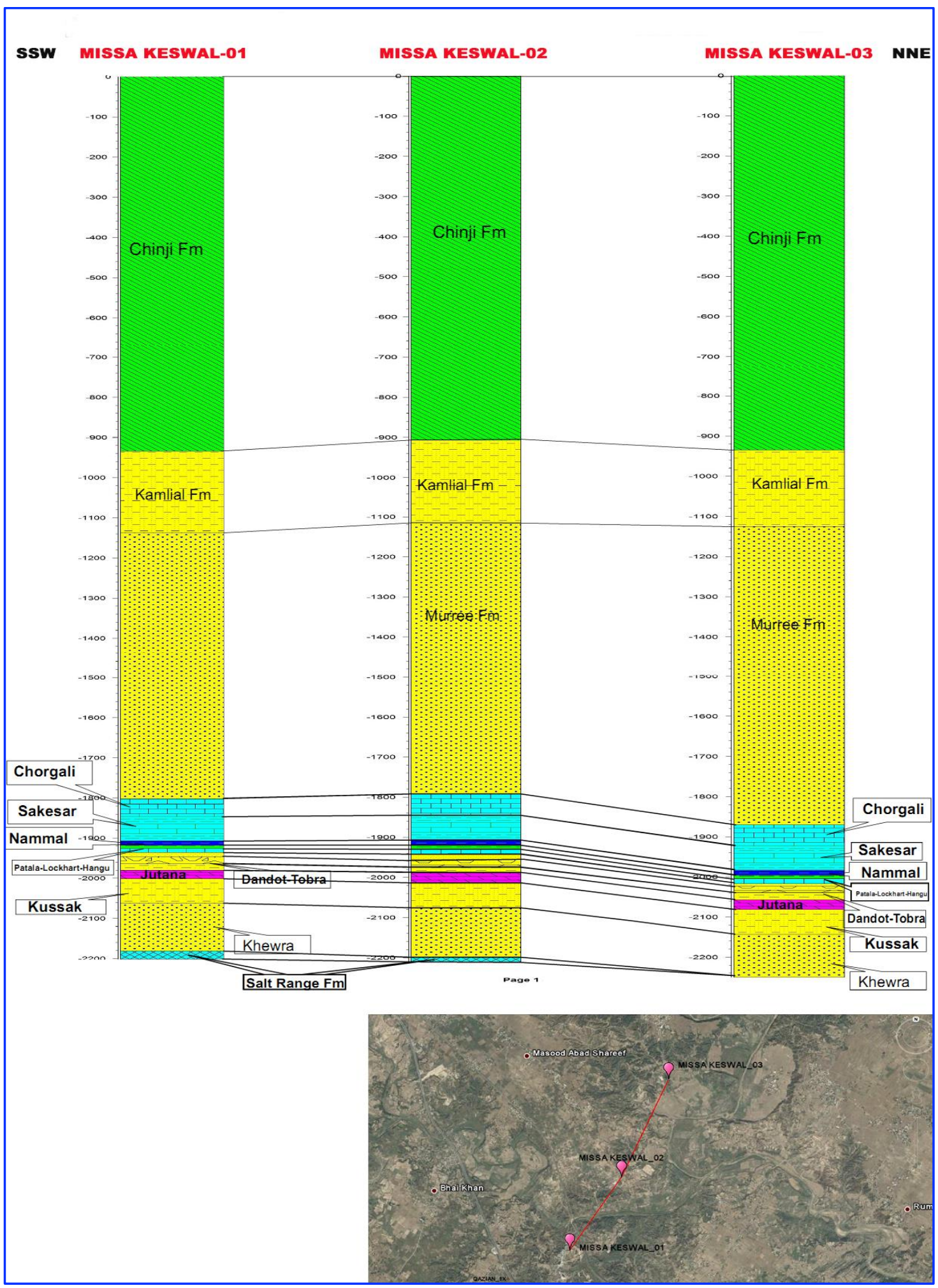

Fig. 10. Strike oriented (SSW to NNE) correlation of different wells of Missa Keswal area. The distance between Missa Keswal-01 and Missa Keswal-02 is $2.61 \mathrm{Km}$, Missa Keswal-02 and Missa Keswal-03 is 3.29 Km while the Missa Keswal-01 and Missa Keswal-03 are 5.91 Km far apart 


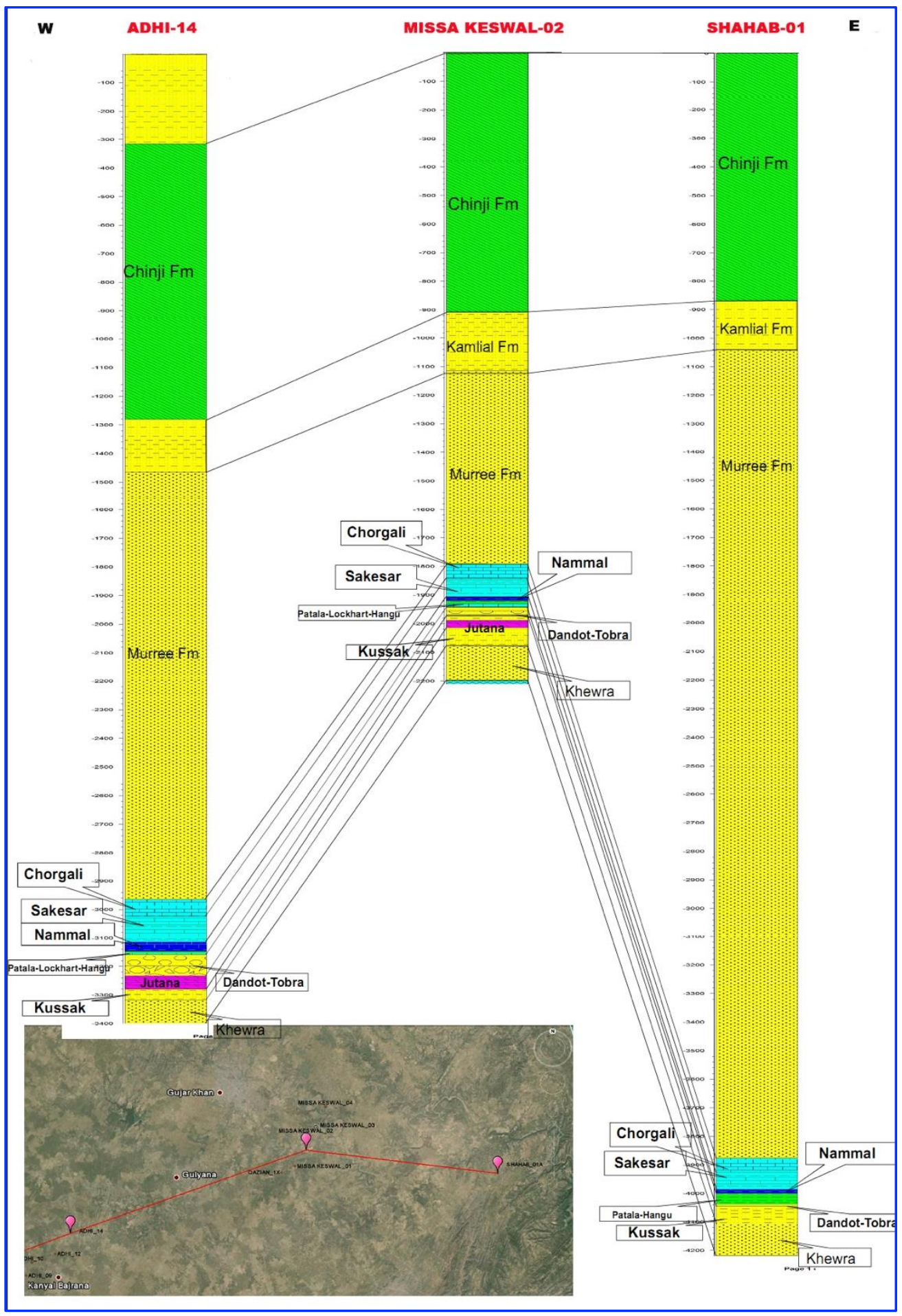

Fig. 11. Dip oriented (E-W) correlation of different wells of eastern part of Potwar Basin. Missa Keswal-02 and Shahab-01 are $24.8 \mathrm{Km}$, Adhi-14 and Missa Keswal-02 is $31.9 \mathrm{Km}$ while Shahab-01 and Adhi-14 are $55 \mathrm{Km}$ far apart

\subsection{Comparative Structural Analysis of Missa Keswal Area and Potwar Basi}

Missa Keswal area marked the eastern part of the Potwar Basin and bounded by thrust faults in the SE-side while on NW-side by back thrust. It bears pop-up, salt cored, anticlinal structure with NESW orientation. Jhelum strike slip fault has significant role in developing the Missa Keswal anticline. But in case of Potwar Basin, it thrust sheet which has NNE transport direction that generally develops 
anticlines have EEN-WWS trending. The basin bounded by two strike slip faults from east and west (Fig. 2). Both strike slip faults are play important roles to determine the orientation of the anticlines. Anticlines near to Jhelum left lateral strike slip fault have NE-SW trending whereas anticlines near the western strike slip fault have NW-SE trending.

\section{Discussion}

Potwar Basin pertains severe structural deformation style. It is divided into two different zones (Fig. 2) named Northern Potwar Deformed Zone (NPDZ) and Southern Potwar Platform Zone (SPPZ). Missa Keswal area is located on the eastern part of the Potwar Basin (SPPZ). The tectonic framework of the study is mainly controlled by strike slip movement along trust fault due to the closeness with left lateral Jhelum strike slip fault and decollement layer i.e., Pre-Cambrian salt. Due to this decollement layer, surficial structures were not giving the true picture of subsurface structures (Moghal et al. 2007). Due to this reason, seismic lines and well data along with the geological data are used to interpret the true subsurface structure of the study area. Asymmetric salt cored, anticlinal folding is present in which north-western limb is steeper as compared to south-eastern limb, that one was quite gentle. Overall, the thrust along with its imbrication dipping towards north-western side while opposite dip direction noticed in case of back thrust. Paleocene (Lockhart Limestone) and Eocene limestones (Sakesar Limestone and Chorgali Formation) are potential reservoirs for hydrocarbons as suggested by Khan et al. 2019 and Lisa and Satti, 2010. Structural restoration should be done to get the better results that how much shortening prevailed in this area. Moreover, to know the true length of lead/prospect, fault seal analysis, is beneficial, if carried out are some future recommendations

\section{Conclusions}

The subsurface structure of the study area was interpreted to be the plunging anticline and bounded by thrust faults in the SE-side while on NW-side by back thrust. The anticlinal structure was pop-up with salt cored delineated by SE dipping back thrust while reverse faulting delineated the SE side of the gently dipped limb. All these features are the indicator of the compressional regime. Salt cored, pop-structure was formed due to the upward lifting of the central block, by decollement layer, along the fault surfaces. Jhelum strike slip fault also controlling the tectonics of the study area. This pop-up, anticlinal structure is an ideal case for hydrocarbon entrapment. The perfect sealing mechanism was provided by the reverse fault and Neogene clays. Eocene limestones i.e., Chorgali Formation and Sakesar Limestone, and Paleocene limestone (Lockhart Limestone) can act as a good reservoir while the Patala Formation has the potential to generate hydrocarbons and can act as a source rock.

\section{Acknowledgements}

The authors acknowledged the Directorate General of Petroleum Concessions (DGPC), Pakistan, for the provision of seismic lines and well data to study the subsurface structure of the Missa Keswal area. The authors are also thankful to IHS for providing a license of Kingdom Suite 8.8 software. The authors are very grateful to the Editor in Chief Prof. Dr. Salih M. Awadh, the Secretary of Journal Mr. Samir R. Hijab. and the Technical Editors for their great efforts and valuable comments.

\section{References}

Aamir, M., Siddiqui, M. M., 2006. Interpretation and visualization of thrust sheets in a triangle zone in eastern Potwar, Pakistan. Journal of Leading Edge, 25(1), 24-37.

Ahsan, N., Miraj, M.A.F., Rehman, S.U., Ali, A., 2013. Subsurface structural reconstruction of Joya Mair structure, Southeast Potwar Sub-Basin, Indus Basin, Pakistan. International Journal of Applied Agricultural Sciences, 5(1), 17-26. 
Ali, K. K., Kadhim, G. F., 2020. 3D Seismic attributes interpretation of Zubair Formation in Al-Akhaideir Area, Southwestern Karbala. Iraqi Geological Journal, 53(1D), 17-25.

Bouilhol, P., Jagoutz, O., Hanchar, J. M., Dudas, F. O., 2013. Dating the India-Eurasia collision through arc magmatic records. Earth and Planetary Science Letters, 366, 163-175.

Davis, D. M., Lillie, R. J., 1994. Changing mechanical response during continental collision: active examples from the foreland thrust belts of Pakistan. Journal of Structural Geology, 16(1), 21-34.

DiPietro, J. A., Pogue, K. R., 2004. Tectonostratigraphic subdivisions of the Himalaya: A view from the west. Tectonics, 23(5), 1-20.

Drewes, H., 1995. Tectonics of the Potwar Plateau region and the development of syntaxes, Punjab, Pakistan. US Government Printing Office, 2126.

Farah, A., Lawrence, R.D., DeJong, K.A., 1984. An overview of the tectonics of Pakistan. In: Haq, B.U., Milliman, J.D. (Eds.), Marine geology and oceanography of Arabian Sea and coastal Pakistan. New York, Van Nostrand Reinhold, 161-176.

Gill, M. W. A., Rajaran, K., 2009. Tectonic activities in Pakistan. Pakistan Meteorological Department, Pakistan.

Moghal, M. A., Saqi, M. I., Hameed, A., Bugti, M. N., 2007. Subsurface geometry of Potwar sub-basin in relation to structuration and entrapment. Pakistan Journal of Hydrocarbon Research, 17, 61-72.

Jadoon, I. A., Hinderer, M., Wazir, B., Yousaf, R., Bahadar, S., Hassan, M., Jadoon, S., 2015. Structural styles, hydrocarbon prospects, and potential in the Salt Range and Potwar Plateau, north Pakistan. Arabian Journal of Geosciences, 8(7), 5111-5125.

Kazmi, A. H., Rana, R.A., 1982. Tectonic map of Pakistan. Geological Survey of Pakistan, Quetta. Scale 1:2, 000, 000.

Khan, F., Mohibullah, M., Khan, M.Y., 2019. Integrated 2D seismic interpretation of Missa Keswal area and petrophysical analysis of Missa Keswal well-03 in Potwar sub-basin, Gujar Khan, Punjab Province, Pakistan. International Research Journal of Earth Sciences, 7(2), 27-38.

Khan, M.A., Ahmed R., Raza, H.A., Kemal, A., 1986. Geology of petroleum in Kohat-Potwar depression, Pakistan. American Association of Petroleum Geologist Bulletin, 70, 396-414.

Lisa, M., Satti, I.A., 2010. Geophysical modeling of a part of Potwar (Missa Keswal) area by using seismic and well data. Journal of Himalayan Earth Sciences, 43, 113.

Powell, C. M. A., 1979. A Speculative Tectonic History of Pakistan and Surroundings: Some Constraints from the Indian Ocean in Geodynamics of Pakistan. In: Dejong, K., Farah, A. (Eds.), Geodynamics of Pakistan. Geological Survey of Pakistan, 5-24.

Quadri, V. N., Quadri, S. M. J. G., 1998. Pakistan has unventured regions, untested plays. Oil Gas Journal, 96(12).

Searle, M.P., Windley, B.F., Coward, M.P., Cooper, D.J.W., Rex, A.J., Rex, D., Tingdong, L., Xuchang, X., Jan, M.Q., Thakur, V.C., Kumar, S., 1987. The closing of Tethys and the tectonics of the Himalaya. Geological Society of America Bulletin, 98, 678-701.

Valdiya, K. S., 2002. Emergence and evolution of Himalaya: reconstructing history in the light of recent studies. Progress in Physical Geography, 26 (3), 360-399.

Wandrey, C.J., Law, B.E., Shah, H.A., 2004. Patala-Nammal composite total petroleum system, Kohat Potwar Geology Province, Pakistan. United States Geological Survey, 2208-B.

Yeats, R.S., Lawrence, R.D., 1984. Tectonics of the Himalayan thrust belt in northern Pakistan. In: Haq, B.U., Milliman, J.D. (Eds.), Marine geology and oceanography of Arabian Sea and coastal Pakistan. New York, Van Nostrand Reinhold, 177-198.

Yin, A., Harrison, T. M., 2000. Geologic evolution of the Himalayan-Tibetan orogen. Annual review of earth and planetary sciences, 28(1), 211-280. 